\title{
EFEITO DA POPULAÇÃO INFETIVA DE Dalbulus maidis NA PRODUÇÃO DE GRÃOS E NO DESENVOLVIMENTO DE SINTOMAS DO ENFEZAMENTO VERMELHO DO MILHO
}

\author{
CLÁUDIA M. TOFFANELLI \& IVAN P. BEDENDO ${ }^{1}$ \\ Departamento de Entomologia, Fitopatologia e Zoologia Agrícola, ESALQ-USP, Cx Postal 9, CEP 13418-900, \\ Piracicaba, SP, e-mail: ipbedend@carpa.ciagri.usp.br
}

(Aceito para publicação em 26/10/2001)

Autor para correspondência: Ivan P. Bedendo

TOFFANELLI, C.M. \& BEDENDO, I.P. Efeito da população infetiva de Dalbulus maidis na produção de grãos e no desenvolvimento de sintomas do enfezamento vermelho do milho. Fitopatologia Brasileira 27:082-086. 2002.

\section{RESUMO}

O enfezamento vermelho, causado por fitoplasma, é uma doença que vem aumentando significativamente de importância, em função dos plantios sucessivos de milho (Zea mays). A transmissão ocorre por meio de cigarrinhas, destacando-se a espécie Dalbulus maidis. Com o objetivo de determinar o efeito da população infetiva de $D$. maidis sobre a produção e o desenvolvimento de sintomas, plantas do híbrido suscetível XLX 520, com dez dias de idade, foram experimentalmente inoculadas com fitoplasma, utilizando populações de um, três, seis e nove insetos por planta, confinados por quatro dias para o período de inoculação. Como tratamentos testemunha, foram utilizadas plantas infestadas com um, três, seis e nove insetos sadios e plantas não infestadas por cigarrinhas. Nas plantas infetadas, os sintomas mais evidentes foram avermelhamento foliar, enfezamento generalizado e proliferação de espigas improdutivas. Rendimento e qualidade de grãos, bem como altura de plantas foram reduzidos à medida em que se aumentou a população de insetos infetivos. Incidência da doença e intensidade de sintomas foram maiores nas plantas inoculadas com as maiores densidades de insetos. Reduções médias de 35,$0 ; 53,7 ; 65,7$ e $91,3 \%$ foram constatadas quando se avaliou a produção de plantas inoculadas com um, três, seis e nove insetos infetivos, respectivamente. Assim, é possível que quanto mais alta a população de insetos infetivos, maior a quantidade de inóculo inicial transmitido às plantas e maior o efeito da doença sobre as mesmas.

Palavras-chave adicionais: Zea mays, molicutes, cigarrinha do milho.

\section{ABSTRACT \\ Effect of infective population of Dalbulus maidis on kernel yield and symptoms development associated with the maize bushy stunt phytoplasma}

The importance of maize bushy stunt caused by a phytoplasma is increasing due to successive corn (Zea mays) cultivation. The pathogen is transmitted mainly by the leafhopper Dalbulus maidis. In order to evaluate the effect of infective population of the vector on grain yield and severity of symptoms, ten-day old plants of the susceptible hybrid XLX-520 were inoculated with one, three, six and nine insects, for a four-day feeding period. Control plants were infested with healthy insects or were not submitted to insect feeding. The most common symptoms observed were red leaves, stunt and ear proliferation. Grain yield, kernel quality and the height of plants were reduced as the infective population increased. Furthermore, the incidence and intensity of symptoms were greater as the infective population increased. Yield reductions of $35.0,53.7,65.7$, and $91.3 \%$ were obtained when plants were inoculated with one, three, six and nine infective insects, respectively. It is possible that a larger infective insect population results in a higher initial inoculum amount and consequently, a stronger effect of the disease on the plants.

\section{INTRODUÇÃO}

O enfezamento vermelho do milho (Zea mays L.) é uma doença causada por fitoplasma, um procarioto sem parede celular, limitado ao floema e transmitido por cigarrinhas, pertencente ao Grupo I-B (Granados, 1969; Lee et al., 1998; Bedendo et al., 2000). Relatado no Brasil na década de 70, o enfezamento foi considerado uma doença de importância secundária devido à baixa incidência (Costa et al., 1971). A partir dos anos 80, a expansão dos plantios denominados "safrinha" e a adoção de irrigação por pivô central proporcio- naram a presença de milho no campo durante o ano inteiro, em grandes áreas. Isso acarretou mudanças no comportamento de alguns patossistemas, principalmente naqueles envolvendo insetos vetores (Oliveira et al., 1997). Em particular, o enfezamento vermelho vem aumentando significativamente de importância, sendo os prejuízos variáveis em função de plantios tardios e suscetibilidade dos híbridos (Silva, 1991).

A cigarrinha Dalbulus maidis (DeLong \& Wolcott) (Homoptera: Cicadellidae) é a principal espécie vetora e transmite o fitoplasma de maneira persistente e propagativa (Nault, 1980). Daubulus maidis tem assumido papel 
relevante nos últimos anos, principalmente nas regiões Sudeste e Centro Oeste do Brasil (Waquil et al., 1999). Os picos populacionais de $D$. maidis têm sido registrados nos meses de março e abril, contribuindo para a disseminação do enfezamento (Waquil, 1992). Embora existam dados mostrando que as maiores incidências da doença estiveram correlacionadas com as maiores densidades do inseto (Oliveira et al., 1998), existem evidências de que a variação do nível de insetos infetivos dentro da população é que determina maior ou menor grau de incidência da doença no campo (Hruska et al., 1996; Folegatti et al., 1997; Massola et al., 1999a). No entanto, tem sido constatado que altas taxas de incidência corresponderam a grandes reduções na produção ( Scott et al., 1977; Oliveira et al., 1998; Massola et al.,1999a).

Em razão da importância da doença, este trabalho foi realizado com o objetivo de investigar o papel da população de insetos infetivos sobre o estabelecimento e desenvolvimento da doença em plantas de milho, bem como avaliar o seu efeito sobre a produção e qualidade de grãos.

\section{MATERIAL E MÉTODOS}

$\mathrm{O}$ ensaio foi conduzido em condições de telado. Sementes pré-germinadas do híbrido suscetível XLX-520 foram plantadas em copos plásticos $(250 \mathrm{ml})$, contendo mistura esterilizada de solo, areia e matéria orgânica, mantendo-se uma planta/copo.

No décimo dia após o plantio, as plantas foram experimentalmente inoculadas com fitoplasma, por meio de um, três, seis e nove insetos infetivos por planta. Como testemunhas foram utilizadas plantas infestadas com um, três, seis e nove insetos sadios por planta e plantas não infestadas por inseto. Os insetos foram confinados sobre as plantas através de gaiolas, representadas por garrafas plásticas de refrigerante de dois litros de capacidade. Após período de inoculação de quatro dias, insetos e ovos foram eliminados por pulverização de inseticida. Aos 20 dias após a inoculação, as plantas foram transferidas para sacos plásticos de cinco litros, contendo a mesma mistura de substrato utilizada nos copos. O delineamento experimental adotado foi inteiramente casualizado com seis repetições, sendo cada parcela constituída por uma planta. A análise estatística dos dados obtidos nos diferentes tratamentos foi realizada utilizando o programa SAS for Windows (SAS Institute, Cary, NC, USA).

A colônia de insetos sadios foi obtida a partir de plantas de milho contendo posturas de adultos sadios de D. maidis. As plantas foram mantidas em caixas teladas e com a eclosão das ninfas, iniciou-se a criação massal. A obtenção de insetos infetivos foi feita de acordo com a metodologia descrita por Nault (1980). Ninfas de $2^{0}$ e $3^{0}$ ínstars, criadas em plantas sadias, foram confinadas no cartucho de plantas infetadas do híbrido XL 333, com cerca de 75 dias de idade, por meio de um saco de tecido voal preso ao ápice da planta. O período de aquisição foi de quatro dias, sendo as ninfas transferidas para plantas sadias, nas quais permaneceram por 21 dias, corres- pondendo ao período de latência. A manutenção de plantas fontes durante o ensaio foi feita mediante passagens sucessivas de insetos infetivos para plantas sadias.

A determinação da presença de fitoplasma e ausência de espiroplasma nas plantas fontes e nas plantas inoculadas foi feita com amostras da penúltima folha do topo, através das técnicas de PCR e de PTA-ELISA, respectivamente. O PCR foi conduzido segundo a metodologia descrita por Lee et al. (1993) e Gundersen \& Lee (1996), sendo que o teste de PTA-ELISA seguiu a metodologia descrita por Green (1982). Os iniciadores universais para fitoplasmas utilizados no duplo PCR foram mF2/mR1 (5'-catgcaagtcgaacgga-3'/5'-cttaaacccc aatcatcgac-3') seguidos de F2n/R2 (5' -gaaacgactgctaagactgg3'/5'-tgacgggeggtgtgtacaaaccceg-3'). No PTA-ELISA foi utilizado antissoro policlonal específico para o espiroplasma do milho, gentilmente fornecido pelo Dr. R.L. Nault, OARDC, $\mathrm{OH}$, USA.

A partir da inoculação, foram feitas observações visuais dos sintomas típicos da doença como clorose e avermelhamento foliar, redução no comprimento de entre-nós, enfezamento da planta e proliferação de espigas. No estádio de grão pastoso, foram avaliados a altura de plantas, o número de espigas/planta e a incidência da doença. Espigas maduras foram colhidas e secas a $105 \pm 2{ }^{\circ} \mathrm{C}$ por $24 \mathrm{~h}$ e os valores das pesagens foram corrigidos para $12 \%$ de umidade. Para cada um dos tratamentos, foram determinados os parâmetros de produção através da determinação do peso de grãos, comprimento de espigas e número de fileiras de grãos nas espigas. O tamanho de grãos foi avaliado pelo teste de retenção, utilizando-se oito peneiras de malhas circulares, cujo diâmetro variou de 7,14 a 9,52 mm. A germinação de sementes foi medida pelo teste padrão, de acordo com as regras para análise de sementes (Brasil, 1992).

\section{RESULTADOS}

Os primeiros sintomas da doença apareceram a partir dos 30 dias após a inoculação, sendo observado, inicialmente, estrias cloróticas nos bordos e ápice das folhas. Com o progresso da doença, houve desenvolvimento de avermelhamento nestas áreas cloróticas. Foram constatados também sintomas do tipo folhas retorcidas, perfilhos laterais, brotações axilares nas folhas, entre-nós e pendões curtos, colmos afilados, enfezamento de plantas, proliferação de espigas anormais e alta ocorrência de grãos mal formados. Os sintomas visuais, considerando-se o conjunto formado por avermelhamento, proliferação de espigas e altura de plantas, foram mais intensos à medida em que se aumentou o número de insetos infetivos confinados às plantas. Plantas infestadas por insetos sadios e plantas não submetidas à infestação de cigarrinhas não mostraram qualquer tipo de sintoma relacionado à doença. A técnica de PCR confirmou a presença de fitoplasma nas plantas fontes e naquelas sintomáticas amostradas durante a condução do ensaio. Contrariamente, o teste PTA-ELISA demonstrou a ausência de espiroplasma nestas plantas, mostrando que as mesmas não apresentavam infecções mistas. 
Níveis crescentes de incidência da doença foram proporcionais ao número de insetos infetivos utilizados nas inoculações (Tabela 1). Nas plantas inoculadas com um inseto, somente uma de um total de seis plantas manifestou sintomas; no entanto, quando as plantas foram inoculadas com seis e nove insetos, sintomas da doença foram observados em cinco e seis plantas, respectivamente. A altura de plantas foi significativamente reduzida nas plantas inoculadas com seis e nove insetos, atingindo valores médios de redução da ordem de $36,4 \%$ e de $44,2 \%$, respectivamente (Tabela 1 ).

A produção de grãos pelas plantas inoculadas foi significativamente menor, independentemente do número de insetos (Tabela 1). Quando um, três, seis e nove insetos foram empregados na inoculação, foram constatadas reduções na produção da ordem de $35,0 \% ; 53,6 \% ; 65,6 \%$ e $91,3 \%$, respectivamente. Os dados revelaram também que a infestação com insetos sadios não interferiu de modo significativo na produção das plantas.

A produção de espigas anormais extranumerárias, caracterizadas por serem de tamanho reduzido e mal formadas, foi significativamente maior nas plantas inoculadas, as quais apresentaram, em média, 4,5 espigas/ planta (Tabela 2). Plantas não infestadas apresentaram somente uma espiga normal/planta.

A redução no tamanho das espigas foi significativa nas plantas inoculadas com seis e nove insetos, atingindo valores de $49,3 \%$ e de $70,3 \%$, respectivamente, em relação às plantas testemunhas não infestadas por insetos (Tabela 2). Estas plantas apresentaram espigas com número médio em torno de 12-13 fileiras de grãos/espiga, enquanto espigas originárias de plantas inoculadas com nove insetos apresentaram a metade deste número (Tabela 2). O número de grãos por espiga também foi reduzido de modo significativo

TABELA 1- Incidência do enfezamento vermelho e valores médios da altura e produção de grãos de plantas do híbrido de milho (Zea mays) XLX 520, não submetidas à alimentação de insetos, submetidas a insetos sadios e inoculadas com insetos infetivos

\begin{tabular}{|c|c|c|c|}
\hline Tratamento & Incidência & $\begin{array}{c}\text { Altura } \\
(\mathbf{m})^{\mathrm{a}}\end{array}$ & $\begin{array}{l}\text { Produção de } \\
\operatorname{grãos}^{\mathrm{a}}(\mathrm{g} / \mathrm{pl})\end{array}$ \\
\hline Plantas não infestadas & $0 / 6$ & $2,33 \mathrm{a}$ & $109,03 \mathrm{a}$ \\
\hline 1 inseto sadio & $0 / 6$ & $2,33 \mathrm{a}$ & $92,19 \mathrm{ab}$ \\
\hline 3 insetos sadios & $0 / 6$ & $2,25 \mathrm{a}$ & $99,44 \mathrm{ab}$ \\
\hline 6 insetos sadios & $0 / 6$ & $2,45 \mathrm{a}$ & $80,70 \mathrm{abc}$ \\
\hline 9 insetos sadios & $0 / 6$ & $2,15 \mathrm{a}$ & $92,52 \mathrm{ab}$ \\
\hline 1 inseto infetivo & $1 / 6$ & $2,03 \mathrm{a}$ & 70,92 bc \\
\hline 3 insetos infetivos & $2 / 6$ & $2,14 \mathrm{a}$ & $50,51 \mathrm{~cd}$ \\
\hline 6 insetos infetivos & $5 / 6$ & $1,48 \quad b$ & 37,42 \\
\hline 9 insetos infetivos & $6 / 6$ & $1,30 \mathrm{~b}$ & 9,47 \\
\hline $\mathrm{CV} \%$ & & 12,57 & 23,84 \\
\hline
\end{tabular}

${ }^{a}$ Valores médios de seis plantas por tratamento. Médias seguidas pelas mesmas letras na coluna não diferem entre si pelo teste de Tukey, ao nível de $5 \%$ de probabilidade. nas plantas inoculadas com nove insetos (Tabela 2). Assim, um número médio de 63,16 grãos/espiga foram contados neste tratamento, enquanto a média para plantas não infestadas foi de 381,3 , o que corresponde a uma redução de $83,4 \%$ nas plantas infetadas.

Quanto ao tamanho dos grãos, para plantas não infestadas por vetor, somente $8,6 \%$ dos grãos produzidos ficaram retidos ou passaram pela peneira de malha de menor diâmetro $(7,14 \mathrm{~mm})$. No entanto, para plantas inoculadas com um, três, seis e nove insetos, 24,$9 ; 40,6 ; 70,0$ e $83,2 \%$ dos grão produzidos foram retidos ou passaram por esta mesma peneira, respectivamente. Esses dados demonstraram que a quantidade de grãos miúdos produzidos pelas plantas inoculadas foi diretamente proporcional ao número de insetos infetivos.

As menores porcentagens de germinação foram constatadas para as sementes originárias de plantas inoculadas com maiores números de insetos. Assim, 93,0\% e $83,5 \%$ de germinação foram obtidas para as sementes produzidas pelas plantas inoculadas com seis e nove insetos infetivos, respectivamente. Em contraste, as sementes de plantas inoculadas por um e três insetos apresentaram taxas próximas de $100 \%$, valores idênticos aos de plantas testemunhas não infestadas.

\section{DISCUSSÃO}

Os sintomas observados nas plantas inoculadas foram basicamente aqueles relatados para plantas infetadas com o fitoplasma do enfezamento (Oliveira et al., 1998; Bedendo, 1999; Massola et al., 1999a), sendo a intensidade variável de acordo com o número de insetos utilizados nas inoculações.

Avaliações de campo, realizadas nas condições brasileiras, têm demonstrado que os enfezamentos têm

TABELA 2 - Valores médios dos componentes da produção do híbrido de milho (Zea mays) XLX 520, inoculado com fitoplasma através de diferentes populações de insetos infetivos

\begin{tabular}{lccccc}
\hline \multirow{2}{*}{ Tratamento } & \multicolumn{5}{c}{ Componentes da produção } \\
\cline { 2 - 6 } & \multicolumn{2}{c}{ NE } & CE & NF & NG \\
\hline Plantas não infestadas & 1.0 & $\mathrm{~b}$ & $14,5 \mathrm{a}$ & $12,6 \mathrm{a}$ & $381,3 \mathrm{a}$ \\
1 inseto sadio & 1.0 & $\mathrm{~b}$ & $13,9 \mathrm{a}$ & $13,0 \mathrm{a}$ & $325,0 \mathrm{ab}$ \\
3 insetos sadios & 1.0 & $\mathrm{~b}$ & $13,3 \mathrm{a}$ & $14,6 \mathrm{a}$ & $368,6 \mathrm{a}$ \\
6 insetos sadios & $1.0 \mathrm{~b}$ & $12,8 \mathrm{a}$ & $13,3 \mathrm{a}$ & $307,3 \mathrm{ab}$ \\
9 insetos sadios & $1.0 \mathrm{~b}$ & $13,2 \mathrm{a}$ & $12,3 \mathrm{a}$ & $328,6 \mathrm{ab}$ \\
1 inseto infetivo & $1.6 \mathrm{ab} *$ & $11,1 \mathrm{ab}$ & $13,3 \mathrm{a}$ & $254,6 \mathrm{ab}$ \\
3 insetos infetivos & $1.3 \mathrm{~b}^{*}$ & $11,0 \mathrm{ab}$ & $13,0 \mathrm{a}$ & $248,1 \mathrm{ab}$ \\
6 insetos infetivos & $2.0 \mathrm{ab} *$ & $7,5 \mathrm{bc}$ & $10,6 \mathrm{ab}$ & $200,6 \mathrm{bc}$ \\
9 insetos infetivos & $4.5 \mathrm{a}^{*}$ & 4,3 & $\mathrm{c}$ & $6,5 \quad \mathrm{~b}$ & $63,16 \mathrm{c}$ \\
\hline CV \% & 21,31 & 18,5 & 11.22 & 18,36 \\
\hline
\end{tabular}

${ }^{a}$ Componentes da produção: valores médios de seis plantas por tratamento). NE: número espigas/planta (* espigas anormais); CE: comprimento espiga (cm); NF: número fileiras/espiga; NG número grãos/espiga. Médias seguidas pelas mesmas letras na coluna não diferem entre si pelo teste de Tukey, ao nível de $5 \%$ de probabilidade. 
Efeito da população infetiva de Dalbulus maidis na produção de...

ocorrido com alta incidência atingindo valores variáveis de $65,3 \%$ a $100 \%$, com predominância da forma vermelha (Oliveira et al., 1998). Em levantamentos realizados no estado de São Paulo, foram constatadas porcentagens de incidência de até $47 \%$ para alguns híbridos suscetíveis (Dudienas et al., 1997). Alta incidência da doença no campo tem sido atribuída à presença de uma alta população de $D$. maidis (Oliveira et al., 1998) e, mais especificamente, à população realmente infetiva do inseto dentro da população total (Hruska \& Peralta 1997; Folegatti et al., 1997; Massola et al., 1999a). No entanto, estas observações foram feitas sem que se conhecesse a porcentagem de insetos infetivos presentes na população de campo. Os resultados obtidos no presente trabalho demonstraram a existência de uma correspondência direta entre o aumento de incidência e o aumento de insetos infetivos, demonstrando ser válidas as suposições feitas pelos autores citados. A ocorrência de redução na altura de plantas inoculadas seguiu a tendência verificada para sintomas e incidência. Esta redução era esperada, pois tem sido um dos sintomas mais comumente observados em plantas infetadas por fitoplasmas (Nault, 1980; Shurtleff, 1986; Bedendo, 1999).

A redução na produção de grãos foi proporcional à população de insetos infetivos e à incidência de enfezamento. Estes resultados obtidos para inoculação isolada de fitoplasma são concordantes com trabalhos de campo conduzidos com o complexo do enfezamento. Assim, Massola et al. (1999a), demonstraram que para cada $1 \%$ de aumento na incidência de enfezamentos no campo, houve $0,8 \%$ de redução na produção de grãos. Em plantios comerciais, instalados no Brasil Central, altos níveis de incidência foram relacionados com alta redução na produção de grãos, havendo áreas onde a produção foi nula (Oliveira et al., 1998). Scott et al. (1977) também revelaram que a produção foi reduzida em até $50 \%$, devido à alta freqüência de ocorrência de enfezamentos, porém chegou a ser nula quando as plantas foram infetadas nos primeiros estádios de desenvolvimento. A qualidade da produção também ficou comprometida, pois uma alta proporção de grãos miúdos foi produzida pelas plantas inoculadas, de forma semelhante ao que constataram Massola et al. (1999b) quando plantas foram inoculadas com espiroplasma.

A produção de espigas anormais foi constantemente observada, chegando a dobrar e quadruplicar nas plantas inoculadas com seis e nove insetos. Nestas espigas foram observadas também a deformação das extremidades das brácteas, as quais passaram a desenvolver estruturas semelhantes a folhas. A proliferação de espigas mal formadas tem sido um sintoma comumente observado em plantas infetadas por fitoplasma (Nault, 1980; Shurtleff, 1986; Oliveira et al., 1998; Bedendo, 1999; Massola et al., 1999a).

A menor ou maior redução no tamanho das espigas, número de fileiras por espiga e número de grãos por espiga pode ser atribuída à menor ou maior suscetibilidade do híbrido. Este tipo de informação é inédita, pois mesmo os trabalhos que relatam proliferação de espigas anormais em plantas infetadas não fazem considerações sobre estes parâmetros (Nault, 1980; Shurtleff, 1986; Oliveira et al., 1998; Bedendo, 1999; Massola et al., 1999a).

Analisando-se o ensaio como um todo, ficou demonstrado que existe efeito da população infetiva de insetos sobre os sintomas, a incidência da doença e a produção de plantas inoculadas. Maior número de insetos infetivos significa, possivelmente, maior quantidade de inóculo inicial transmitido às plantas. Partindo-se desta premissa, é justificável que plantas que receberam maior carga de inóculo desenvolveram a doença de forma mais severa, o que acarretou maiores perdas na produção.

\section{AGRADECIMENTOS}

Os autores manifestam seus agradecimentos aos professores Décio Barbin e Sônia Piedade do Setor de Matemática e Estatística da ESALQ/USP pela colaboração nas análises estatísticas. Aos engenheiros agrônomos Roberto de Carvalho da Dinamilho e Ivan Rezende da Monsanto, pelo fornecimento de sementes.

\section{REFERÊNCIAS BIBLIOGRÁFICAS}

BEDENDO, I.P. Enfezamento vermelho e enfezamento pálido do milho associados a fitoplasma e espiroplasma: sintomatologia, etiologia e técnicas para detecção e identificação destes agentes. Summa Phytopathologica 25:190-196. 1999.

BEDENDO, I.P., DAVIS, R.E. \& DALLY, E.L. Detection and identification of the maize bushy stunt phytoplasma in corn plants in Brazil using PCR and RFLP. International Journal of Pest Management 46:73-76. 2000.

BRASIL. Ministério da Agricultura e Reforma Agrária. Regras para Análise de Sementes. Brasília, DF. 1992.

COSTA, A.S., KITAJIMA, E.W. \& ARRUDA, S.C. Moléstia de vírus e de micoplasma do milho em São Paulo. Revista da Sociedade Brasileira de Fitopatologia 4:39-41. 1971.

DUDIENAS, C., DUARTE, A.P., PATERNIANI, M.E., RIBEIRO, J.L., BIANCHINI, M.T., KANTHACH, R.A., CASTRO, J.L., SILVEIRA,L.C., DENUCCI, S., SABINO JÚNIOR, J., BOLONHESI, D. \& DE SORDI, G. Severidade de doenças no milho "safrinha" no Estado de São Paulo em 1996. Anais, IV Seminário sobre a Cultura do Milho Safrinha, Assis, SP. 1997. pp.107-115.

FOLEGATTI, M.E.G., LOPES, J.R.S., AMORIM, L., SILVA, W.J., SOLFERINO, O.B., SILVA, H.P. \& PEREIRA, O.A.P. Incidência de enfezamento do milho e população do vetor Dalbulus maidis, em diferentes localidades e épocas de plantio, na safra 95/96. Fitopatologia Brasileira 22:347. 1997.

GRANADOS, R.R. Electron microscopy of plants and insect vectors infected with the corn stunt disease agent. Contribution Boyce Thompson Institute 24:173-187. 1969.

GREEN, S.J. Detection of corn stunt spiroplasma in vivo by ELISA using antisera to extracts from infected corn plant (Zea mays L.). Plant Pathology 31:289-297. 1982.

GUNDERSEN, D.E. \& LEE, I.M. Ultrasensitive detection of phytoplasmas by nested-PCR assays using two universal primer pairs. Phytopathology Mediterranea 35:144-151. 1996.

HRUSKA, A.J., GLADSTONE, S.M. \& OBANDO, R. Epidemic roller coaster: maize stunt disease in Nicaragua. American 
Entomologist 42:248-252. 1996.

HRUSKA, A.J. \& PERALTA, M.G. Maize response to corn leafhopper (Homoptera: Cicadellidae) infestation and achaparramiento disease. Journal of Economic Entomology 90:604-610. 1997.

LEE, I.M., HAMMOND, R.W., DAVIS, R.E. \& GUNDERSEN, D.E. Universal amplification and analysis of pathogen 16S rDNA for classification and identification of mycoplasmalike organism. Phytopathology 83:834-842. 1993.

LEE, I.M., GUNDERSEN, D.E., DAVIS, R.E. \& BARTOSZIK, I.M. Revised classification scheme of phytoplasmas based on RFLP analyses of $16 \mathrm{~S}$ rRNA and ribossomal protein gene sequences. International Journal of Systematic Bacteriology 48:1153-1169. 1998.

MASSOLA, N.S., BEDENDO, I.P., AMORIM, L. \& LOPES, J.R.S. Quantificação de danos causados pelo enfezamento vermelho e enfezamento pálido do milho em condições de campo. Fitopatologia Brasileira 24:136-142.1999a.

MASSOLA, N.S., BEDENDO, I.P. AMORIM, L. \& LOPES, J.R.S. Effects of the inoculation time on corn with Spiroplasma kunkelii on yield components. Fitopatologia Brasileira 24:571573. 1999b.

NAULT, L.R. Maize bushy stunt and corn stunt: a comparison of disease symptoms, pathogen host ranges, and vectors.
Phytopathology 70:659-662. 1980.

OLIVEIRA, E., WAQUIL, J.M., FERNANDES, F.T., PAIVA, E., RESENDE, R.O. \& KITAJIMA, E.W. Enfezamento pálido e enfezamento vermelho na cultura do milho no Brasil Central. Fitopatologia Brasileira 23:45-47. 1998.

OLIVEIRA, E., WAQUIL, J.M. \& PINTO, N.F.J.A. Doenças causadas por patógenos transmitidos por insetos: complexo enfezamento/mosaico. Anais, IV Seminário sobre a Cultura do Milho Safrinha, Assis, SP. 1997. pp.87-94.

SCOTT, G.E., ROSEKRANZ, E.E., NELSON, L.R. Yield losses of corn due to corn stunt disease complex. Agronomy Journal 69:92-94. 1977.

SHURTLEFF, M.C. Compendium of Corn Disease $2^{\text {nd }}$ ed. St. Paul. American Phytopathological Society.1986.

SILVA, H.P. Identificação e controle das doenças de milho. Informativo Coopercitrus 6:18-24. 1991.

WAQUIL, J.M. Flutuação populacional da cigarrinha do milho Dalbulus maidis no Centro Nacional de Pesquisa de Milho e Sorgo (CNPMS). Resumos, $19^{\circ}$ Congresso Nacional de Milho e Sorgo, Porto Alegre, RS. 1992. p.68.

WAQUIL, J.M., VIANA, P.A., CRUZ, I. \& SANTOS, J.P. Aspectos da biologia da cigarrinha-do-milho, Dalbulus maidis (DeLong and Wolcott) (Hemiptera: Cicadellidae). Anais da Sociedade Entomológica do Brasil 28:413-420. 1999. 